\title{
Dissolution Behavior and Stabilization of Fluorine in Secondary Refining Slags
}

\author{
Hideaki SUITO and Ryo INOUE \\ Institute of Multidisciplinary Research for Advanced Materials, Tohoku University, Katahira, Aoba-ku, Sendai, Miyagi-ken 980- \\ 8577 Japan.
}

(Received on January 22, 2002; accepted in final form on April 6, 2002)

\begin{abstract}
Dissolution of fluorine in secondary refining and synthetic $\mathrm{CaO}-\mathrm{SiO}_{2}-\mathrm{Al}_{2} \mathrm{O}_{3}\left(-\mathrm{P}_{2} \mathrm{O}_{5}\right)$ slags has been studied by using the shaking test and its behavior is discussed based on the results for the time dependence of $\mathrm{Ca}$, $\mathrm{Si}, \mathrm{Al}$ and $\mathrm{F}$ contents in aqueous solution. It was found that fluorine dissolution is affected by the contents of $\mathrm{SiO}_{2}, \mathrm{~F}$ and total $\mathrm{Fe}$ in slag and particularly its effect is obvious in synthetic slags. The dissolved fluorine from slags with low contents of $\mathrm{SiO}_{2}$ and total Fe can be immobilized through the incorporation of fluorine into precipitated hydrates such as $\mathrm{CaO}-\mathrm{Al}_{2} \mathrm{O}_{3}-\mathrm{H}_{2} \mathrm{O}$ compound and $\mathrm{CaO}-\mathrm{SiO}_{2}-\mathrm{Al}_{2} \mathrm{O}_{3}-\mathrm{H}_{2} \mathrm{O}$ gel. In the case of slags with high $\mathrm{SiO}_{2}$ and low total Fe contents, the dissolved fluorine can be immobilized through the formation of $\mathrm{CaO}-\mathrm{SiO}_{2}-\mathrm{H}_{2} \mathrm{O}-\mathrm{SO}_{4}-\mathrm{F}$ gel by the addition of gypsum to aqueous solution. The dissolution behavior of fluorine in seawater has been also studied.
\end{abstract}

KEY WORDS: secondary refining slag; fluorine; immobilization; $\mathrm{CaO}-\mathrm{Al}_{2} \mathrm{O}_{3}-\mathrm{H}_{2} \mathrm{O}$ compound; $\mathrm{CaO}-\mathrm{SiO}_{2}-$ $\mathrm{Al}_{2} \mathrm{O}_{3}-\mathrm{H}_{2} \mathrm{O}$ gel; gypsum; $\mathrm{CaO}-\mathrm{SiO}_{2}-\mathrm{H}_{2} \mathrm{O}-\mathrm{SO}_{4}-\mathrm{F}$ gel; seawater.

\section{Introduction}

Fluorine-bearing mineral phases in secondary refining slags have been previously studied by using X-ray diffraction and microprobe analysis. ${ }^{1)}$ It was found that fluorine is contained in calcium aluminates such as $12 \mathrm{CaO}$. $7 \mathrm{Al}_{2} \mathrm{O}_{3}$ and $3 \mathrm{CaO} \cdot \mathrm{Al}_{2} \mathrm{O}_{3}, 2 \mathrm{CaO} \cdot \mathrm{Al}_{2} \mathrm{O}_{3} \cdot \mathrm{SiO}_{2}$ and $12 \mathrm{CaO}$. $(7-x) \mathrm{Al}_{2} \mathrm{O}_{3} \cdot x \mathrm{Fe}_{2} \mathrm{O}_{3}$ phases and is present at fluoride minerals such as $11 \mathrm{CaO} \cdot 7 \mathrm{Al}_{2} \mathrm{O}_{3} \cdot \mathrm{CaF}_{2}$ and $\left(2 \mathrm{CaO} \cdot \mathrm{SiO}_{2}\right)_{2} \cdot \mathrm{CaF}_{2}$. Furthermore, the saturated value of fluorine in aqueous solution dissolved from $11 \mathrm{CaO} \cdot 7 \mathrm{Al}_{2} \mathrm{O}_{3} \cdot \mathrm{CaF}_{2}$ was considerably small in comparison with that from other F-containing mineral phases. ${ }^{1)}$ It was shown in previous study ${ }^{2)}$ that fluorine dissolved from hot metal pretreatment slags can be stabilized by using secondary refining slags. In this case the fluorine immobilization process by using secondary refining slag ( $\mathrm{SR}$ slag hereinafter) with low contents of $\mathrm{SiO}_{2}$ and total $\mathrm{Fe}$, namely high content of $\mathrm{Al}_{2} \mathrm{O}_{3}$, proceeds rapidly, while that by using SR slags with high $\mathrm{SiO}_{2}$ and low total Fe contents proceeds slowly. The rapid immobilization by the former SR slag is explained by the fact that F ion dissolved from hot metal slags is substituted by $\mathrm{OH}^{-}$site in calcium aluminum hydrates such as $\mathrm{Ca}_{3} \mathrm{Al}_{2}(\mathrm{OH})_{12}$ and $3 \mathrm{CaO} \cdot \mathrm{Al}_{2} \mathrm{O}_{3} \cdot \mathrm{Ca}(\mathrm{OH})_{2} \cdot 18 \mathrm{H}_{2} \mathrm{O}^{2,3)}$ precipitated during shaking test.

Hot metal pretreatment slags containing F demonstrated higher dissolution tendency in seawater, and it was found that fluorine was immobilized by the formation of $\left.\mathrm{Mg}(\mathrm{OH}, \mathrm{F})_{2}{ }^{4}\right)$

In the present study the dissolution behavior of fluorine in $\mathrm{SR}$ and synthetic $\mathrm{CaO}-\mathrm{Al}_{2} \mathrm{O}_{3}-\mathrm{SiO}_{2}\left(\mathrm{P}_{2} \mathrm{O}_{5}\right)$ slags has been studied by using the shaking test and F-bearing hydration products have been identified by using X-ray diffraction and electron microprobe analysis. Furthermore, the immobilization of $\mathrm{F}$ in SR slags through the formation of $\mathrm{CaO}-$ $\mathrm{SiO}_{2}-\mathrm{SO}_{4}-\mathrm{H}_{2} \mathrm{O}-\mathrm{F}$ gel has been discussed based on the results for the shaking test where gypsum is added. The dissolution behavior of fluorine in seawater is also reported.

\section{Experimental}

The synthetic slag of secondary refining was prepared as follows: Analytical grade $\mathrm{CaCO}_{3}, \mathrm{SiO}_{2}, \mathrm{Al}_{2} \mathrm{O}_{3}$ and $\mathrm{CaF}_{2}$ were mixed to have the compositions of $\mathrm{CaO} / \mathrm{Al}_{2} \mathrm{O}_{3}$ molar ratio $=3.0,0$ to $15 \mathrm{mass} \% \mathrm{SiO}_{2}$ and 1.5 to 8.0 mass $\% \mathrm{~F}$ and was melted at $1550^{\circ} \mathrm{C}$ under Ar atmosphere in a graphite crucible. Then it was quenched rapidly using water cooled $\mathrm{Cu}$ mold in order to obtain glassy slag. For the preparation of slowly cooled slag, the melt was cooled to $800^{\circ} \mathrm{C}$ at a rate of $150^{\circ} \mathrm{C} / \mathrm{h}$, followed by quenching using water cooled $\mathrm{Cu}$ mold. For the slag with high $\mathrm{SiO}_{2}$ content, $\mathrm{P}_{2} \mathrm{O}_{5}$ ( 1 mass $\%$ ) was added to prevent the dusting of $2 \mathrm{CaO} \cdot \mathrm{SiO}_{2}$ by the transformation from $\beta-2 \mathrm{CaO} \cdot \mathrm{SiO}_{2}$ to $\gamma-2 \mathrm{CaO} \cdot \mathrm{SiO}_{2}$.

Secondary refining and synthetic $\mathrm{CaO}-\mathrm{SiO}_{2}-\mathrm{Al}_{2} \mathrm{O}_{3}\left(-\mathrm{P}_{2} \mathrm{O}_{5}\right)$ slags were ground to $0.5-2.0$ and below $0.1 \mathrm{~mm}$, and these samples were used for the shaking test. The solid sample and aqueous solution were charged in $500 \mathrm{ml}$ polyethylene bottle and were shaken horizontally at a speed of 200 times per min at the solid to liquid ratio of $1 / 10(\mathrm{~g} / \mathrm{m} l)$. More detailed description is given elsewhere. ${ }^{2)}$ The seawater used in the present study was sampled from Pacific Ocean near the coast of Japan. The chemical composition of this seawa- 
Table 1. Chemical compositions and mineral phases containing fluorine in secondary refining slags.

\begin{tabular}{|c|c|c|c|c|c|c|c|c|c|c|c|c|}
\hline SR slag & 13 & $\begin{array}{l}\text { D } \\
\text { po }\end{array}$ & $\begin{array}{c}53 \\
\left(53 r^{*}\right) \\
\text { der }\end{array}$ & $\begin{array}{c}54 \\
\left(54 \mathrm{r}^{*}\right)\end{array}$ & B & 32 & $\begin{array}{l}52 \\
\text { bloc }\end{array}$ & A & $51 \mathrm{r}^{*}$ & $50 r^{*}$ & $\mathrm{E}$ & $\begin{array}{l}\mathrm{C} \\
\mathrm{ck}\end{array}$ \\
\hline$(\% \mathrm{~F})$ & 0.64 & 0.30 & 0.11 & 0.11 & 0.80 & 2.81 & 1.27 & 1.31 & 1.86 & 2.50 & 0.68 & 0.12 \\
\hline$\left(\% \mathrm{SiO}_{2}\right)$ & 16.2 & 13.5 & 15.5 & 15.4 & 8.9 & 8.7 & 5.3 & 4.9 & 5.2 & 5.1 & 6.4 & 7.6 \\
\hline$\left(\% \mathrm{Al}_{2} \mathrm{O}_{3}\right)$ & 27.2 & 30.2 & 24.4 & 27.1 & 28.7 & 35.1 & 35.2 & 33.1 & 30.5 & 31.0 & 29.5 & 15.3 \\
\hline$(\% \mathrm{~T} . \mathrm{Fe})$ & 0.6 & 1.4 & 1.3 & 2.9 & 0.6 & 0.3 & 1.4 & 1.6 & 0.2 & 2.1 & 5.3 & 14.3 \\
\hline $\begin{array}{c}11 \mathrm{CaO} \cdot 7 \mathrm{Al}_{2} \mathrm{O}_{3} \cdot \\
\mathrm{CaF}_{2}\end{array}$ & $\triangle$ & $\triangle$ & - & - & 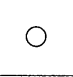 & (a) & O & $\mathrm{O}$ & - & - & $\bigcirc$ & - \\
\hline$\left(2 \mathrm{CaO} \cdot \mathrm{SiO}_{2}\right)_{2} \cdot \mathrm{CaF}_{2}$ & $\triangle$ & $\triangle$ & - & $\triangle$ & - & $\triangle$ & - & - & - & - & O & - \\
\hline $12 \mathrm{CaO} \cdot 7 \mathrm{Al}_{2} \mathrm{O}_{3}$ & $\triangle$ & $\triangle$ & 0 & 0 & $\underset{(0 \sim 1.3)}{(7)}$ & $\bigcirc_{(0.3 \sim 1.9)}^{\bigcirc}$ & $\underset{(0 \sim 1.1)}{(9)}$ & $\stackrel{(0)}{(0 \sim 1.4)}$ & - & - & $\underset{(0 \sim 0.7)}{(9)}$ & $\underset{(0) \sim 0.5}{C}$ \\
\hline $\begin{array}{r}12 \mathrm{CaO} \cdot(7-x) \\
\mathrm{Al}_{2} \mathrm{O}_{3} \cdot x \mathrm{Fe}_{2} \mathrm{O}_{3}\end{array}$ & - & - & - & - & - & - & - & $\triangle$ & - & - & $\bigcirc_{(0 \sim 1) .2)}$ & $\underset{(0 \sim 1) .4)}{(0)}$ \\
\hline $3 \mathrm{CaO} \cdot \mathrm{Al}_{2} \mathrm{O}_{3}$ & - & - & - & - & - & - & $\underset{(0 \sim 0.4)}{\bigcirc}$ & $\underset{(0 \sim 0.5)}{\bigcirc}$ & - & - & - & - \\
\hline $3 \mathrm{CaO} \cdot 2 \mathrm{SiO}_{2}$ & 0 & 0 & 0 & 0 & - & - & - & - & - & - & - & - \\
\hline $2 \mathrm{CaO} \cdot \mathrm{SiO}_{2}$ & 0 & $\bigcirc$ & 0 & 0 & $\underset{(0 \sim 0.8)}{\triangle}$ & $\underset{(0 \sim 1.0)}{\triangle}$ & $\underset{(0 \sim 0.8)}{\triangle}$ & $\underset{(0 \sim 0.8)}{\triangle}$ & - & - & $\underset{(0 \sim 0.5)}{\triangle}$ & $\underset{(0) \sim 0.3 !}{\triangle}$ \\
\hline $2 \mathrm{CaO} \cdot \mathrm{SiO}_{2} \cdot \mathrm{Al}_{2} \mathrm{O}_{3}$ & (2) & (a) & $\bigcirc$ & 0 & - & - & - & - & - & - & - & - \\
\hline
\end{tabular}

ter sample was $0.54 \% \mathrm{Na}-0.02 \% \mathrm{~K}-0.02 \% \mathrm{Ca}-0.05 \% \mathrm{Mg}-$ $0.86 \% \mathrm{Cl}-0.13 \% \mathrm{SO}_{4}-0.00005 \% \mathrm{~F}$ in $\operatorname{mass} \%$.

Sampling was made with a polyethylene whole pipette of $5 \mathrm{ml}$, followed by filtration using the membrane filter (0.1 mm open pore size). The filtrate was introduced into two polycarbonate measuring flasks for analyzing the contents of $\mathrm{F}, \mathrm{Ca}, \mathrm{Al}, \mathrm{Si}, \mathrm{S}$ and $\mathrm{Cl}$. A buffer solution $(40 \mathrm{ml})$ with the composition of $0.4 \mathrm{w} / \mathrm{v} \% \mathrm{CyDTA}-5.8 \mathrm{w} / \mathrm{v} \% \mathrm{NaCl}-$ $5.7 \mathrm{v} / \mathrm{v}$ acetic acid was added to the sample solution for the $\mathrm{F}$ analysis, and $5 \mathrm{ml} \mathrm{HNO}_{3}(1+1)$ was added for the $\mathrm{Ca}, \mathrm{Al}$, $\mathrm{Si}, \mathrm{S}$ and $\mathrm{Cl}$ analysis. The $\mathrm{F}$ content was determined by the selective ion-electrode method (JIS-K-0101) and the contents of $\mathrm{Ca}, \mathrm{Al}, \mathrm{Si}$ and $\mathrm{S}$ were determined by using inductively coupled plasma (ICP) atomic emission spectrometry. The $\mathrm{Cl}$ content was determined by using ICP mass spectrometry. X-ray diffraction analysis and electron microprobe analysis with energy dispersive X-ray (EDX) were used for the identification of mineral phases. The correction was made by ZAF method for EDX analysis. The F content in F-containing minerals was determined by using EPMAwavelength dispersive X-ray (WDX) spectroscopy with the help of the Bence-Albee correction method.

\section{Results and Discussion}

\subsection{Behavior of Fluorine Dissolution}

3.1.1. Dependence of Slag Composition and Cooling Rate a) Slag Composition

The secondary refining slags whose chemical compositions and identified mineral phases containing $\mathrm{F}$ are given in Table 1, are classified into three groups depending on i) high $\mathrm{SiO}_{2}$ and low T.Fe contents (SR-13, -D, -53 and -54), ii) low $\mathrm{SiO}_{2}$ and low T.Fe contents (SR-B, -32, -52, and -A) and iii) low $\mathrm{SiO}_{2}$ and middle or high T.Fe contents (SR-E and $-\mathrm{C}$ ). For the slags containing high $\mathrm{SiO}_{2}$ contents (14 to 16 mass \%) no block sample could be obtained due to the dusting phenomenon of $\alpha^{\prime}$ or $\beta-\mathrm{Ca}_{2} \mathrm{SiO}_{4}$ to $\gamma-\mathrm{Ca}_{2} \mathrm{SiO}_{4}$ in-

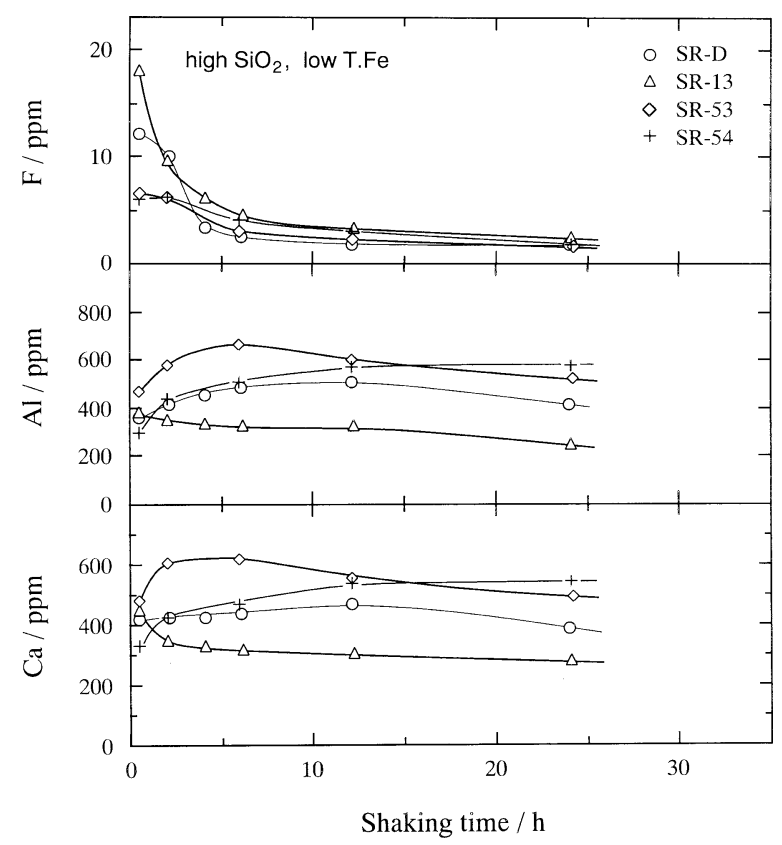

Fig. 1. Variation with shaking time of solute contents dissolved from conventionally cooled secondary refining slags with high $\mathrm{SiO}_{2}$ and low T.Fe contents: grain size $\leq 0.1 \mathrm{~mm}$.

version during cooling. Therefore, the particle size below $0.1 \mathrm{~mm}$ was used for the shaking test. Variations of $\mathrm{F}, \mathrm{Al}$ and $\mathrm{Ca}$ contents with shaking time are shown in Figs. 1 through 3. The $\mathrm{F}$ contents for the slags with low $\mathrm{SiO}_{2}$ and low T.Fe contents shown in Fig. 2 decrease more rapidly at initial time, as compared with those for the slags with high $\mathrm{SiO}_{2}$ and low total $\mathrm{Fe}$ contents and those for the slags with low $\mathrm{SiO}_{2}$ and middle or high total $\mathrm{Fe}$ contents shown in Figs. 1 and 3, respectively. High F content for SR-B slag in Fig. 2 can be explained by the fact that $3 \mathrm{CaO} \cdot \mathrm{Al}_{2} \mathrm{O}_{3}$ is not present in this slag, as given in Table 1. More details for this reason will be explain later in this section. 


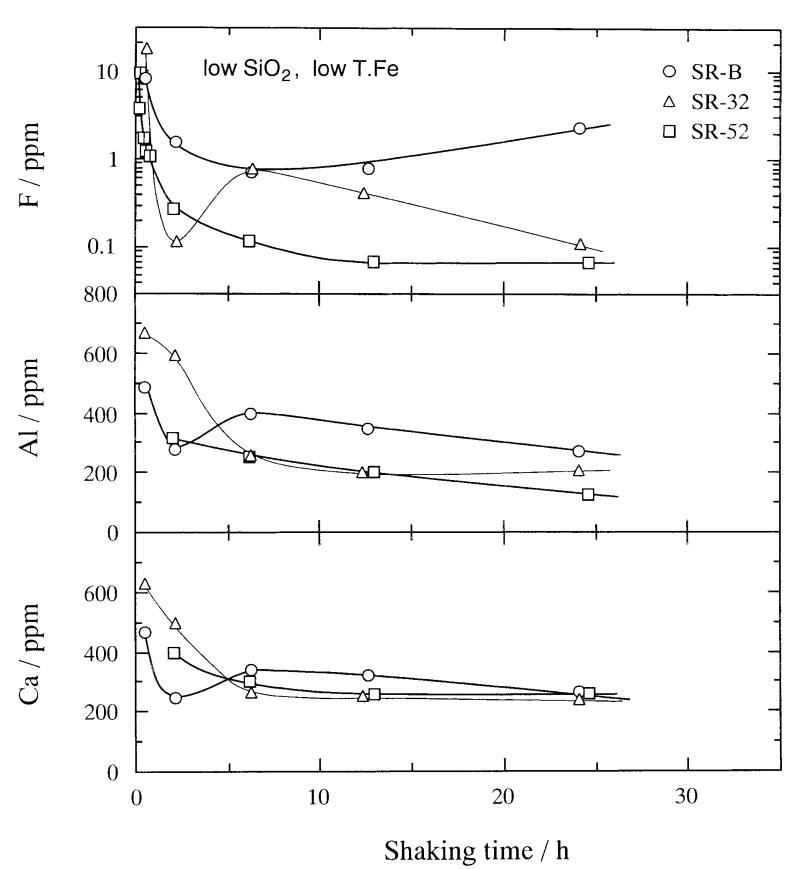

Fig. 2. Variation with shaking time of solute contents dissolved from conventionally cooled secondary refining slags with low $\mathrm{SiO}_{2}$ and low T.Fe contents: grain size $\leq 0.1 \mathrm{~mm}$.

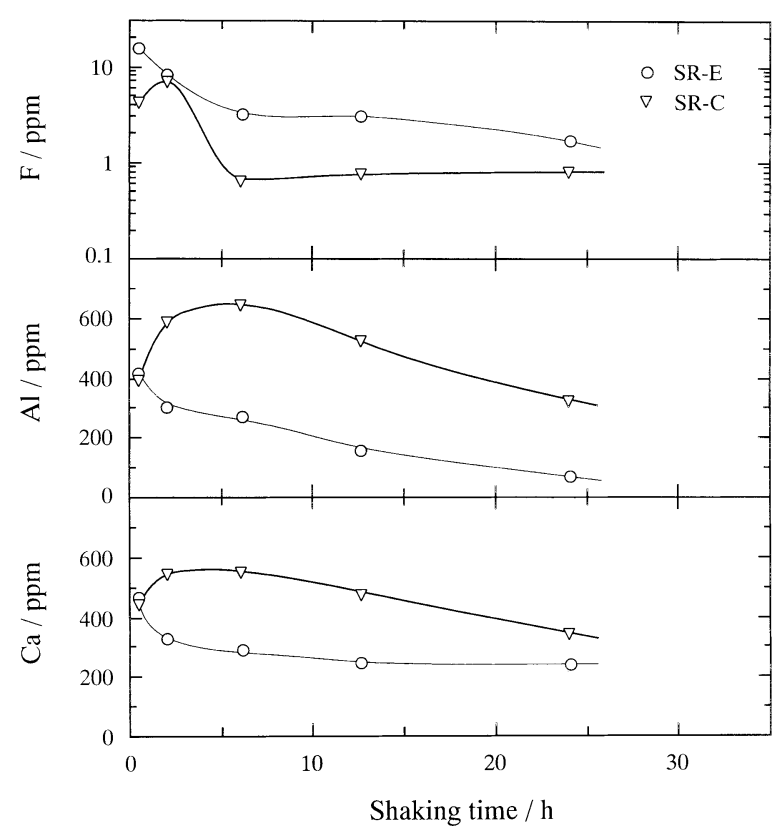

Fig. 3. Variation with shaking time of solute contents dissolved from conventionally cooled secondary refining slags with low $\mathrm{SiO}_{2}$ and middle T.Fe (SR-E) and low $\mathrm{SiO}_{2}$ and high T.Fe (SR-C) contents: grain size $\leq 0.1 \mathrm{~mm}$.

In general, the dissolution behavior of $\mathrm{F}$ in aqueous solution depends on the amount and size of F-containing mineral phases located at the particle surface, the solubility limit of corresponding hydrate, $\mathrm{pH}$ value and other aspects. However, the present results in which the F content decreases with shaking time suggest that the precipitation of Fcontaining hydrates on particle surface and/or in aqueous solution affects the F content, which will be described later.

Most of $\mathrm{F}$ dissolution curves show that the $\mathrm{F}$ content is high at initial period, followed by continuous decrease. However, some SR slags have the maximum (SR-C), the
Table 2. F-containing hydrates observed in the filtered residue after shaking test of SR slags.

\begin{tabular}{|c|c|}
\hline SR slag & F-containing hydrate \\
\hline $\begin{array}{l}\text { high } \mathrm{SiO}_{2} \text { and } \\
\text { low T.Fe }\end{array}$ & $\begin{array}{l}\text { C-S-H-F gel, C-S-A-H-F gel } \\
\mathrm{C}_{1.5 \sim 2.0} \mathrm{SH}_{2}-\mathrm{F}, \mathrm{C}_{2} \mathrm{SH}-\mathrm{F}, \mathrm{C}_{3} \mathrm{~S}_{2} \mathrm{H}-\mathrm{F}\end{array}$ \\
\hline $\begin{array}{l}\text { low } \mathrm{SiO}_{2} \text { and } \\
\text { low T.Fe }\end{array}$ & $\begin{array}{l}\mathrm{Ca}_{3} \mathrm{Al}_{2}(\mathrm{OH}, \mathrm{F})_{12} \\
3 \mathrm{CaO} \cdot \mathrm{Al}_{2} \mathrm{O}_{3} \cdot \mathrm{Ca}(\mathrm{OH}, \mathrm{F})_{2} \cdot 18 \mathrm{H}_{2} \mathrm{O}\end{array}$ \\
\hline $\begin{array}{l}\text { low } \mathrm{SiO}_{2} \text { and } \\
\text { low T.Fe }\end{array}$ & $\begin{array}{l}\mathrm{Ca}_{3}(\mathrm{Al}, \mathrm{Fe})_{2}(\mathrm{OH}, \mathrm{F})_{12} \\
3 \mathrm{CaO} \cdot(\mathrm{Al}, \mathrm{Fe})_{2} \mathrm{O}_{3} \cdot \mathrm{Ca}(\mathrm{OH}, \mathrm{F})_{2} \cdot 18 \mathrm{H}_{2} \mathrm{O}\end{array}$ \\
\hline $\begin{array}{l}\text { high } \mathrm{SiO}_{2} \text { and } \\
\text { low } \mathrm{T} . \mathrm{Fe} \\
\text { (with gypsum) }\end{array}$ & $\begin{array}{l}\mathrm{C}-\mathrm{S}-\mathrm{H}-\mathrm{SO}_{4}-\mathrm{F} \text { gel, C-S-A-H-SO } \\
4-\mathrm{F} \text { gel } \\
\mathrm{Ca} 10\left(\mathrm{SiO}_{4}\right)_{3}\left(\mathrm{SO}_{4}\right)_{3}(\mathrm{OH}, \mathrm{F})_{2} \\
\mathrm{Ca}_{5}\left(\mathrm{SiO}_{4}, \mathrm{SO}_{4}\right)_{3}(\mathrm{OH}, \mathrm{F}) \\
\mathrm{Ca}_{3} \mathrm{Si}\left(\mathrm{SiO}_{4}\right)_{2}(\mathrm{OH}, \mathrm{F})_{6} \cdot 9 \mathrm{H}_{2} \mathrm{O}\end{array}$ \\
\hline $\begin{array}{c}\text { low } \mathrm{SiO}_{2} \text { and } \\
\text { low } \mathrm{T} . \mathrm{Fe} \\
\text { (with gypsum) }\end{array}$ & $\begin{array}{l}\mathrm{Ca}_{6}\left[\mathrm{Al}(\mathrm{OH}, \mathrm{F})_{6}\right]_{2}\left(\mathrm{SO}_{4}\right)_{3} \cdot 26 \mathrm{H}_{2} \mathrm{O} \\
\mathrm{Ca}_{4}\left[\mathrm{Al}(\mathrm{OH}, \mathrm{F})_{6}\right]_{2}\left(\mathrm{SO}_{4}\right) \cdot m \mathrm{H}_{2} \mathrm{O}(m=6,8)\end{array}$ \\
\hline $\begin{array}{c}\text { low } \mathrm{SiO}_{2} \text { and } \\
\text { low } \mathrm{T} . \mathrm{Fe} \\
\text { (with gypsum) } \\
\text { (hydrothermal) }\end{array}$ & $\begin{array}{l}\text { C-S-H-SO }{ }_{4} \text {-F gel, C-S-A-H-SO }{ }_{4}-\mathrm{F} \text { gel } \\
\mathrm{Ca}_{10}\left(\mathrm{SiO}_{4}\right)_{3}\left(\mathrm{SO}_{4}\right)_{3}(\mathrm{OH}, \mathrm{F})_{2} \\
\mathrm{Ca}_{5}\left(\mathrm{SiO}_{4}, \mathrm{SO}_{4}\right)_{3}(\mathrm{OH}, \mathrm{F}) \\
\mathrm{Ca}_{2} \mathrm{Al}_{2} \mathrm{SiO}_{6}(\mathrm{OH}, \mathrm{F})_{2}\end{array}$ \\
\hline
\end{tabular}

C: $\mathrm{CaO}, \mathrm{S}: \mathrm{SiO}_{2}, \mathrm{~A}: \mathrm{Al}_{2} \mathrm{O}_{3}, \mathrm{H}: \mathrm{H}_{2} \mathrm{O}$.

minimum (SR-B) and both (SR-32). It can be said that the measured $\mathrm{F}$ content is determined as a result of the offset of the F dissolution from slag and the precipitation of F-containing hydrates. Such effect is influenced by kind of mineral phase and particle size which will be explained in Sec. 3.1.2.

The hydration products after the shaking test were identified by using XRD and EPMA for the filtered residue and the F-containing hydration products are summarized in Table 2. Fluorine was observed in $\mathrm{C}-\mathrm{S}-\mathrm{H}$ gel for the slags with high $\mathrm{SiO}_{2}$ and low T.Fe contents whose main mineral phases are $\mathrm{C}_{3} \mathrm{~S}, \mathrm{C}_{2} \mathrm{~S}$ and $\mathrm{C}_{2} \mathrm{AS}(\mathrm{C}, \mathrm{S}, \mathrm{A}$ and $\mathrm{H}$ represent $\mathrm{CaO}, \mathrm{SiO}_{2}, \mathrm{Al}_{2} \mathrm{O}_{3}$ and $\mathrm{H}_{2} \mathrm{O}$, respectively). Fluorine for the slags with low $\mathrm{SiO}_{2}$ and low T.Fe contents was stabilized in the form of $\mathrm{Ca}_{3} \mathrm{Al}_{2}(\mathrm{OH}, \mathrm{F})_{12}$ and $3 \mathrm{CaO} \cdot \mathrm{Al}_{2} \mathrm{O}_{3} \cdot \mathrm{Ca}(\mathrm{OH}, \mathrm{F})_{2}$. $18 \mathrm{H}_{2} \mathrm{O}$. ${ }^{3)}$ These hydrates are the hydration products of $\mathrm{C}_{3} \mathrm{~A}$ and $\mathrm{C}_{12} \mathrm{~A}_{7}$, respectively, which are main minerals in the slags with low $\mathrm{SiO}_{2}$ and low T.Fe contents. In the case of the slags with low $\mathrm{SiO}_{2}$ and middle or high T.Fe contents whose main mineral phase is $12 \mathrm{CaO} \cdot 7(\mathrm{Al}, \mathrm{Fe})_{2} \mathrm{O}_{3}$, fluorine was stabilized in the form of $\mathrm{Ca}_{3}(\mathrm{Al}, \mathrm{Fe})_{2}(\mathrm{OH}, \mathrm{F})_{12}$ and/or $3 \mathrm{CaO} \cdot(\mathrm{Al}, \mathrm{Fe})_{2} \mathrm{O}_{3} \cdot \mathrm{Ca}(\mathrm{OH}, \mathrm{F})_{2} \cdot 18 \mathrm{H}_{2} \mathrm{O}$.

It was confirmed in the previous study ${ }^{3,5)}$ that the degree of $\mathrm{F}$ immobilization through the formation of $\mathrm{Ca}_{3} \mathrm{Al}_{2}(\mathrm{OH}$, $\mathrm{F})_{12}$ was higher than that of $3 \mathrm{CaO} \cdot \mathrm{Al}_{2} \mathrm{O}_{3} \cdot \mathrm{Ca}(\mathrm{OH}, \mathrm{F})_{2}$. $18 \mathrm{H}_{2} \mathrm{O}$, and that of $\mathrm{Ca}_{3}(\mathrm{Al}, \mathrm{Fe})_{2}(\mathrm{OH}, \mathrm{F})_{12}$ was lower than that of the aforementioned two hydrates. Furthermore, the degree of $\mathrm{F}$ immobilization by $\mathrm{C}-\mathrm{S}-\mathrm{H}$ gel decreases with increasing $\mathrm{SiO}_{2}$ content in SR slags. This is due to the fact that the hydration rate of calcium aluminum silicate is lower than that of calcium aluminate. The behavior of $\mathrm{Ca}$ and $\mathrm{Al}$ contents in aqueous solution will be described in detail in Sec. 3.1.3.

The major hydrates after the shaking test by using the synthetic slags containing 5 mass $\% \mathrm{~F}$ whose analyzed compositions and mineral phases are given in Table $\mathbf{3}$, are shown in Fig. 4. The particle size is in the range between 
Table 3. Chemical compositions and mineral phases of synthetic $\mathrm{CaO}-\mathrm{SiO}_{2}-\mathrm{Al}_{2} \mathrm{O}_{3}\left(-\mathrm{P}_{2} \mathrm{O}_{5}\right)$ slags and major hydrates after shaking test.

\begin{tabular}{c|cccc|cc|cc}
\hline & $\mathrm{S}-1$ & $\mathrm{~S}-2$ & $\mathrm{~S}-3$ & $\mathrm{~S}-4$ & $\mathrm{~S}-21$ & $\mathrm{~S}-22$ & $\mathrm{~S}-41$ & $\mathrm{~S}-42$ \\
\hline$(\% \mathrm{~F})$ & 5.0 & 5.0 & 5.1 & 5.0 & 2.0 & 8.0 & 1.5 & 8.0 \\
$(\% \mathrm{CaO})$ & 59.2 & 56.0 & 53.3 & 49.2 & 57.9 & 54.2 & 50.9 & 47.3 \\
$\left(\% \mathrm{SiO}_{2}\right)$ & 0 & 5.0 & 9.3 & 15.0 & 5.0 & 5.0 & 15.2 & 15.0 \\
$\left(\% \mathrm{Al}_{2} \mathrm{O}_{3}\right)$ & 35.8 & 34.0 & 31.4 & 29.8 & 35.1 & 32.8 & 31.3 & 28.7 \\
$\left(\% \mathrm{P}_{2} \mathrm{O}_{5}\right)$ & 0 & 0 & 1.0 & 1.0 & 0 & 0 & 1.1 & 1.0 \\
\hline $11 \mathrm{CaO} \cdot 7 \mathrm{Al}_{2} \mathrm{O}_{3} \cdot \mathrm{CaF}_{2}$ & $\bigcirc$ & $\bigcirc$ & $\bigcirc$ & $\triangle$ & $\triangle$ & $\bigcirc$ & - & $\triangle$ \\
$3 \mathrm{CaO} \cdot \mathrm{Al}_{2} \mathrm{O}_{3}$ & $\bigcirc$ & $\bigcirc$ & $\triangle$ & - & $\bigcirc$ & $\bigcirc$ & - & - \\
$12 \mathrm{CaO} \cdot 7 \mathrm{Al}_{2} \mathrm{O}_{3}$ & $\triangle$ & $\bigcirc$ & $\bigcirc$ & $\triangle$ & $\bigcirc$ & $\bigcirc$ & $\triangle$ & $\triangle$ \\
$2 \mathrm{CaO} \cdot \mathrm{SiO}_{2} \cdot \mathrm{Al}_{2} \mathrm{O}_{3}$ & - & - & - & $\bigcirc$ & - & - & $\bigcirc$ & $\bigcirc$ \\
$2 \mathrm{CaO} \cdot \mathrm{SiO}_{2}$ & - & $\triangle$ & $\triangle$ & $\bigcirc$ & $\triangle$ & $\triangle$ & $\bigcirc$ & $\bigcirc$ \\
\hline $\mathrm{Ca} \mathrm{Al}_{2}\left(\mathrm{OH}_{1} \mathrm{~F}\right)_{12}$ & $\bigcirc$ & $\bigcirc$ & $\bigcirc$ & $\triangle$ & $\bigcirc$ & - & $\triangle$ & - \\
$3 \mathrm{CaO} \cdot \mathrm{Al}_{2} \mathrm{O}_{3} \cdot \mathrm{Ca}(\mathrm{OH}$, & $\triangle$ & $\bigcirc$ & $\bigcirc$ & $\bigcirc$ & $\bigcirc$ & $\bigcirc$ & $\bigcirc$ & $\bigcirc$ \\
$\mathrm{F})_{2} \cdot 18 \mathrm{H}_{2} \mathrm{O}$ & $\triangle$ & & & & & & & \\
\hline
\end{tabular}

Amount : $0>\bigcirc>\triangle, \quad-$ not observed.

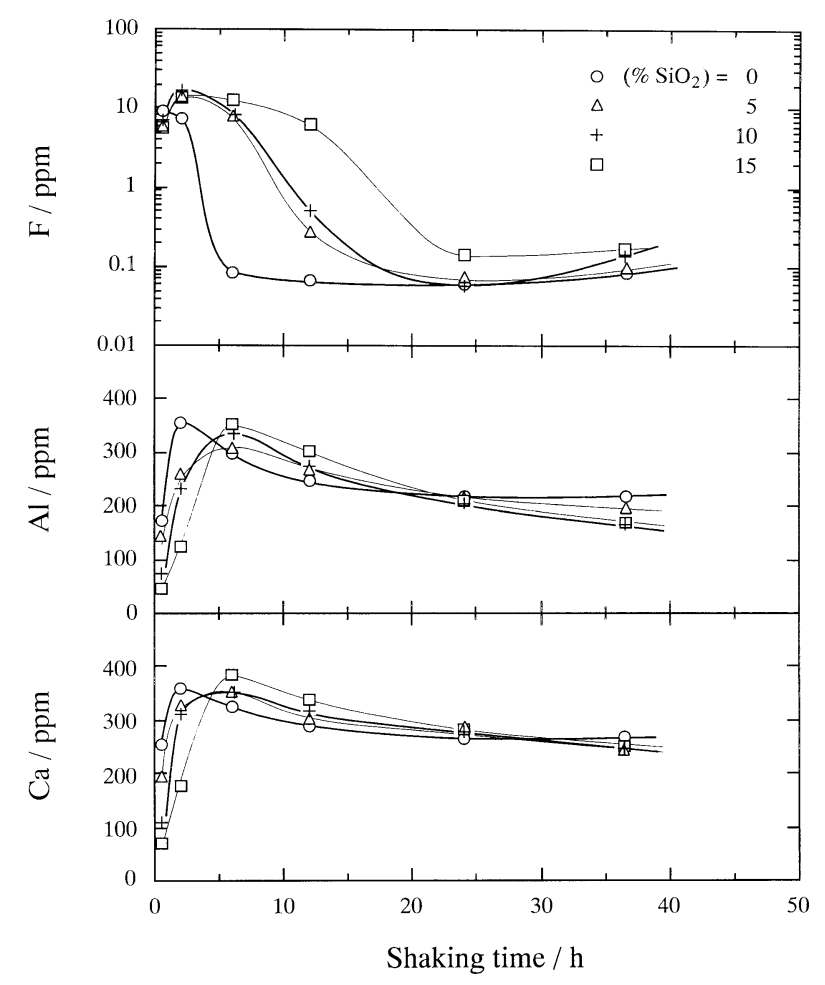

Fig. 4. Variation with shaking time of solute contents dissolved from slowly cooled synthetic slags $\left(X_{\mathrm{CaO}} / X_{\mathrm{Al}_{2} \mathrm{O}_{3}}=3\right.$, $(\% \mathrm{~F})=5)$ as a function of $\mathrm{SiO}_{2}$ content: grain size $0.5-$ $2 \mathrm{~mm}$.

0.5 and $2 \mathrm{~mm}$. Fluorine contents increase initially and then decrease. However, the start of $\mathrm{F}$ decrease tends to be longer with an increase of $\mathrm{SiO}_{2}$ content at constant molar ratio of $\mathrm{CaO} / \mathrm{Al}_{2} \mathrm{O}_{3}=3$. With an increase of $\mathrm{SiO}_{2}$ content from 0 to 15 mass $\%$, main mineral phase changes as $\mathrm{C}_{3} \mathrm{~A} \rightarrow \mathrm{C}_{12} \mathrm{~A}_{7} \rightarrow \mathrm{C}_{2} \mathrm{AS}$ and main hydration product containing $\mathrm{F}$ changes as $\mathrm{Ca}_{3} \mathrm{Al}_{2}(\mathrm{OH}, \mathrm{F})_{12} \rightarrow 3 \mathrm{CaO} \cdot \mathrm{Al}_{2} \mathrm{O}_{3} \cdot \mathrm{Ca}(\mathrm{OH}$, $\mathrm{F})_{2} \cdot 18 \mathrm{H}_{2} \mathrm{O} \rightarrow \mathrm{C}-\mathrm{S}-\mathrm{H}(\mathrm{C}-\mathrm{S}-\mathrm{A}-\mathrm{H})$ gel. The degree of $\mathrm{F}$ im-

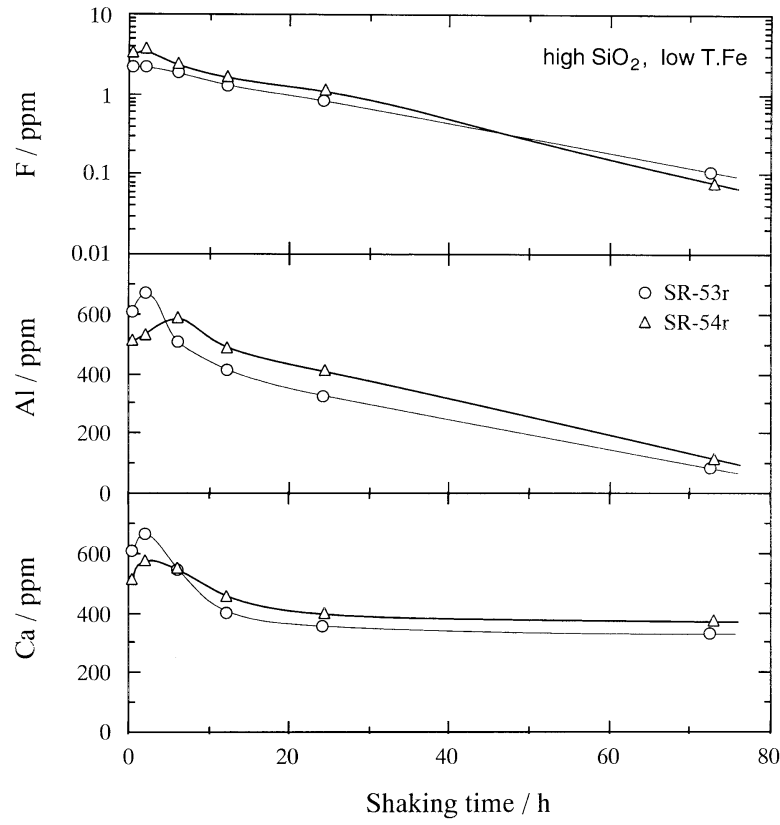

Fig. 5. Variation with shaking time of solute contents dissolved from rapidly quenched secondary refining slags with high $\mathrm{SiO}_{2}$ and low T.Fe contents: grain size $\leq 0.1 \mathrm{~mm}$.

mobilization can be explained by the hydration ability of these calcium aluminates, as observed in previous study. ${ }^{3)}$

b) Cooling Rate

The shaking test was carried out for rapidly cooled SR slags with high $\mathrm{SiO}_{2}$ and low T.Fe contents and the results are shown in Fig. 5. It can be seen that the contents of F, Al and $\mathrm{Ca}$ for rapidly cooled slags decrease more in comparison with those for slowly cooled slags shown in Fig. 1.

The dissolution behavior of $\mathrm{F}, \mathrm{Al}$ and $\mathrm{Ca}$ for rapidly cooled synthetic slags with 0,5 and 15 mass $\% \mathrm{SiO}_{2}$ at constant molar ratio of $\mathrm{CaO} / \mathrm{Al}_{2} \mathrm{O}_{3}=3$ are shown in Fig. 6. The dissolution behavior is different from that for slowly cooled synthetic slags shown in Fig. 4. That is, in the case of the rapidly cooled slag with 15 mass $\% \mathrm{SiO}_{2}$, the $\mathrm{F}$ content remains almost unchanged and the $\mathrm{Al}$ content is considerably lower than that for the slowly cooled slag. The reason for the different behavior with respect to cooling rate is not clear and further study is necessary.

\subsubsection{Dependence of Fluorine Content and Particle Size}

a) Fluorine Content

The influence of $\mathrm{F}$ content in slag on dissolution behavior of $\mathrm{F}$ was studied for slowly cooled synthetic slags with 5 and 15 mass $\% \mathrm{SiO}_{2}$ at constant molar ratio of $\mathrm{CaO} / \mathrm{Al}_{2} \mathrm{O}_{3}=$ 3. The results are shown in Figs. 7 and 8 . In the case of the slags with 5 mass $\% \mathrm{SiO}_{2}$ shown in Fig. 7, the $\mathrm{F}$ dissolution behavior of the slags containing $\mathrm{F}$ up to 5 mass $\% \mathrm{~F}$ is nearly the same. However, in the case of the slags with 15 mass $\% \mathrm{SiO}_{2}$ shown in Fig. 8, the behavior of $\mathrm{F}$ dissolution is dependent on the $\mathrm{F}$ content. This may be explained by different mineral phases, as shown in Table 3.

b) Particle Size

Influence of particle size of SR slags with low $\mathrm{SiO}_{2}$ and low T.Fe contents on the dissolution behavior of $\mathrm{F}, \mathrm{Al}$ and $\mathrm{Ca}$ was studied and the results are shown in Fig. 9. The slag 


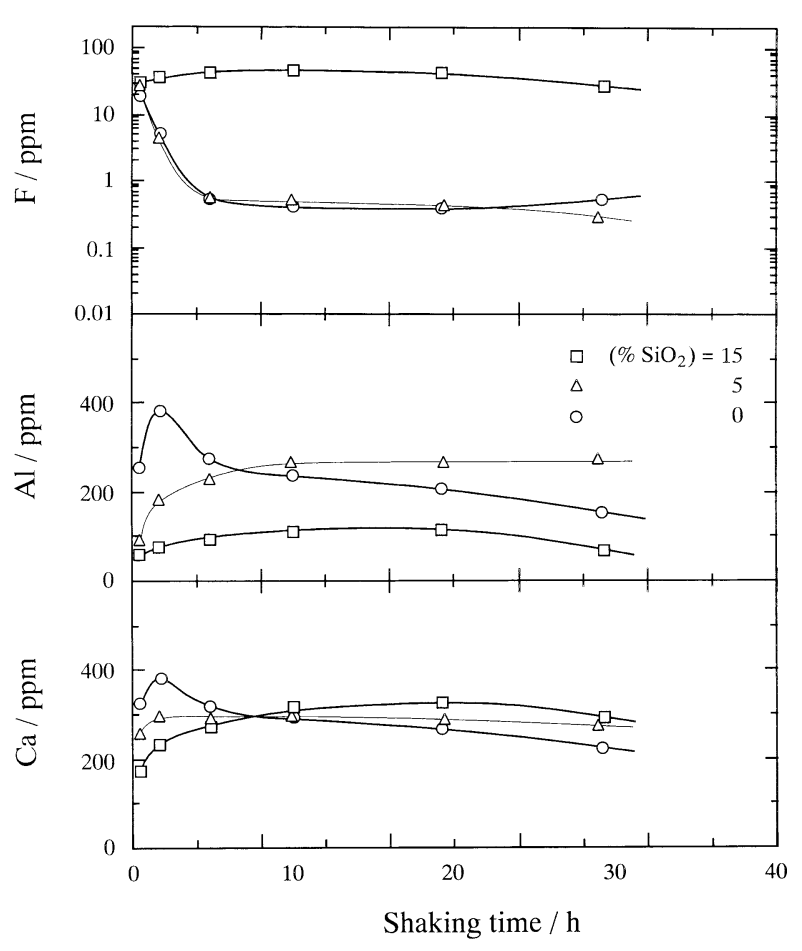

Fig. 6. Variation with shaking time of solute contents dissolved from rapidly quenched synthetic slags $\left(X_{\mathrm{CaO}} / X_{\mathrm{Al}_{2} \mathrm{O}_{3}}=3\right.$, $(\% \mathrm{~F})=5)$ as a function of $\mathrm{SiO}_{2}$ content: grain size $0.5-$ $2 \mathrm{~mm}$.

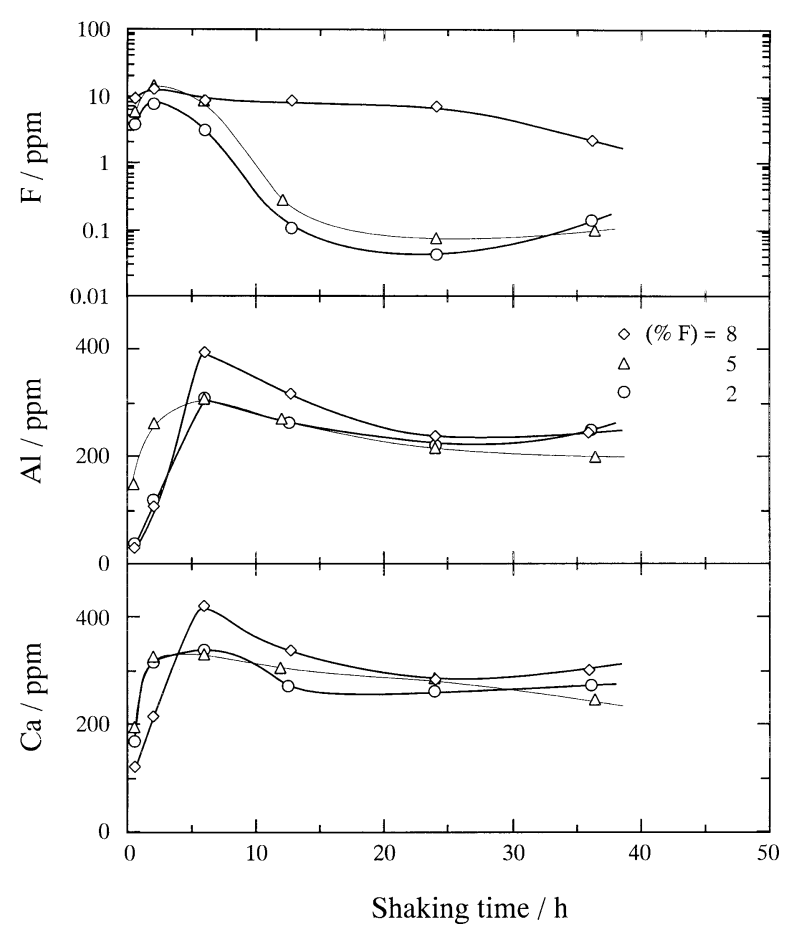

Fig. 7. Variation with shaking time of solute contents dissolved from slowly cooled synthetic slags $\left(X_{\mathrm{CaO}} / X_{\mathrm{Al}_{2} \mathrm{O}_{3}}=3\right.$, $\left.\left(\% \mathrm{SiO}_{2}\right)=5\right)$ as a function of fluorine content: grain size $0.5-2 \mathrm{~mm}$.

dissolution occurs suddenly at initial time regardless of particle size. In the case of the slags with low $\mathrm{SiO}_{2}$ and low T.Fe contents the dissolved $\mathrm{F}$ is incorporated into $\mathrm{Ca}_{3} \mathrm{Al}_{2}(\mathrm{OH})_{12}$ and/or $3 \mathrm{CaO} \cdot \mathrm{Al}_{2} \mathrm{O}_{3} \cdot \mathrm{Ca}(\mathrm{OH}, \mathrm{F})_{2} \cdot 18 \mathrm{H}_{2} \mathrm{O}$, which are precipitated on the particle surface and/or in aqueous solution. This is the reason that the F content in so-

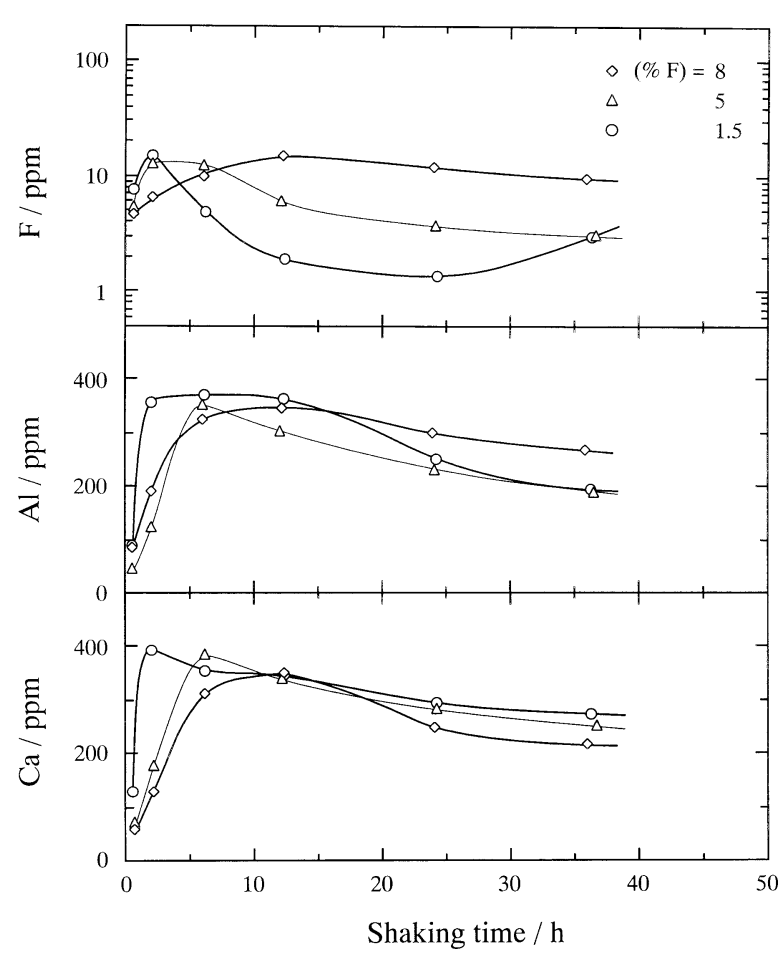

Fig. 8. Variation with shaking time of solute contents dissolved from slowly cooled synthetic slags $\left(X_{\mathrm{CaO}} / X_{\mathrm{Al}_{2} \mathrm{O}_{3}}=3\right.$, $\left.\left(\% \mathrm{SiO}_{2}\right)=15\right)$ as a function of fluorine content: grain size $0.5-2 \mathrm{~mm}$.

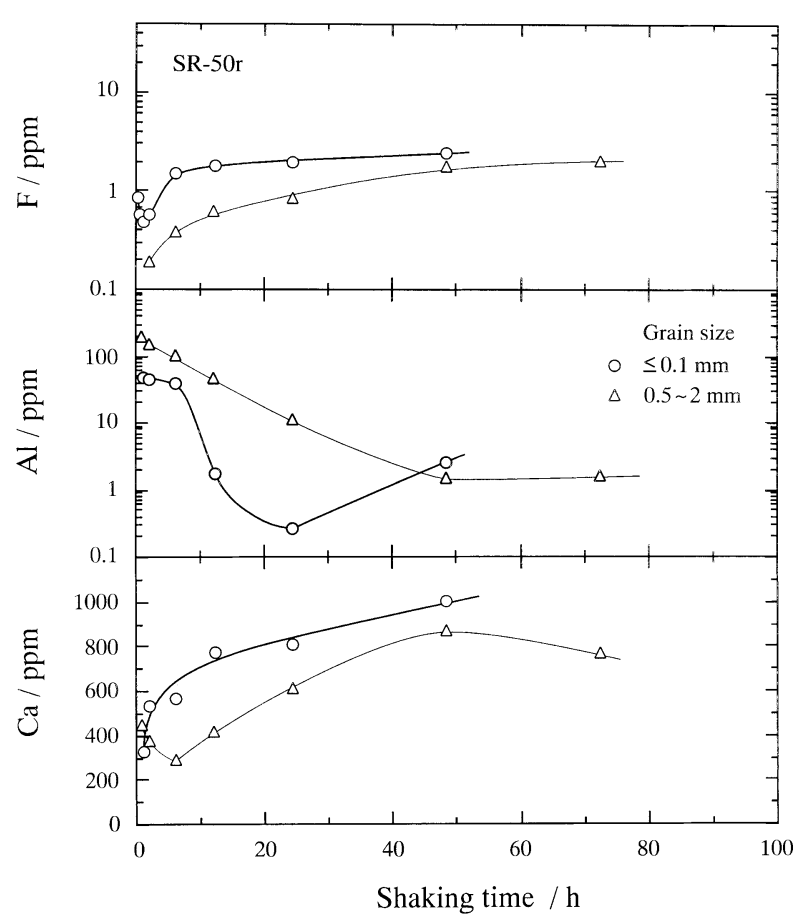

Fig. 9. Effect of grain size of rapidly quenched secondary refining slag on solute contents.

lution decreases at initial period. The increase of $\mathrm{F}$ content after $1 \mathrm{~h}$ is explained by the fact that the $\mathrm{F}$ dissolution rate is higher than the $\mathrm{F}$ incorporation rate. It is apparent that the degree of $F$ increase for small particles is higher than that for larger particles. 

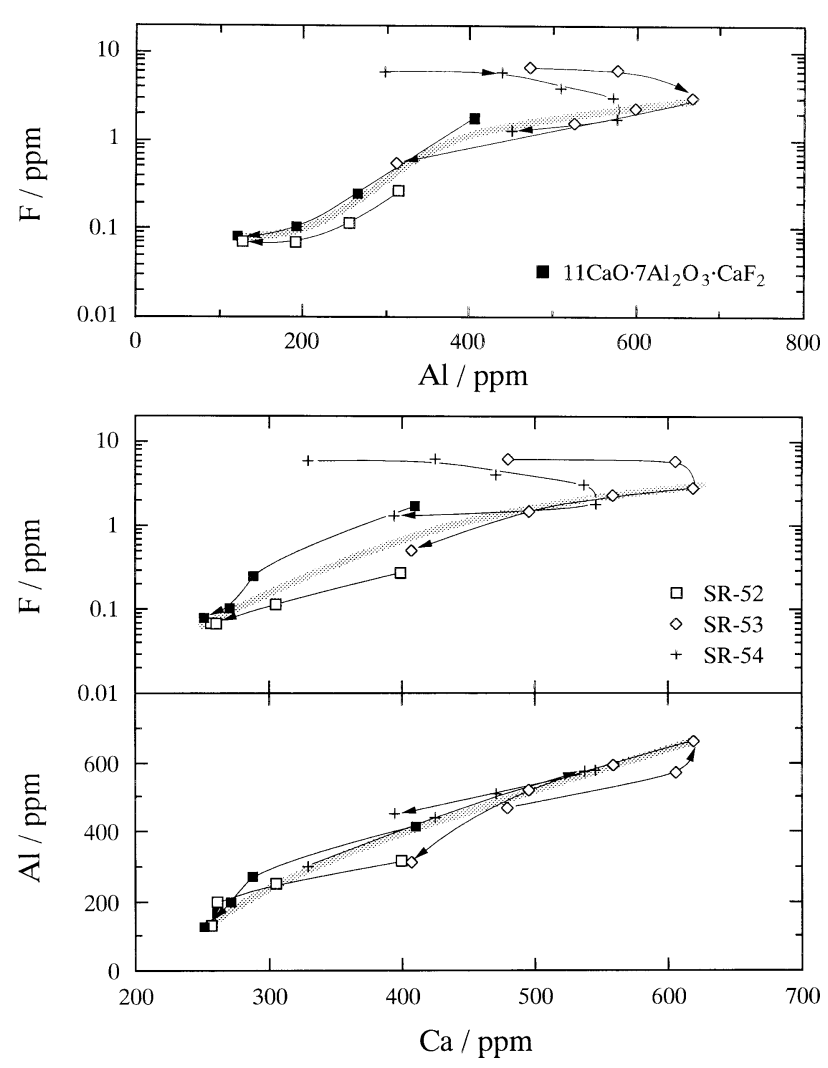

Fig. 10. Relations among solute contents in solution during dissolution of secondary refining slags: grain size $\leq 0.1$ $\mathrm{mm}$.

\subsubsection{Relations among $\mathrm{F}, \mathrm{Al}$ and $\mathrm{Ca}$ Contents}

The relations between $\mathrm{F}$ and $\mathrm{Al}$, between $\mathrm{F}$ and $\mathrm{Ca}$ and between $\mathrm{Al}$ and $\mathrm{Ca}$ contents in aqueous solution are shown in Fig. 10 for the data shown in Fig. 1 (SR-53 and -54) and Fig. 2 (SR-52). The arrow mark represents the lapse of shaking time. It can be seen that the contents of $\mathrm{Al}$ and $\mathrm{Ca}$ increase initially to a considerable degree and then gradually decrease, as shown in the lower diagram. With decreasing the contents of $\mathrm{Al}$ and $\mathrm{Ca}$, the $\mathrm{F}$ contents decrease continuously. As given in Table 1, major mineral phases for SR-52 are $\mathrm{C}_{12} \mathrm{~A}_{7}$ and $\mathrm{C}_{3} \mathrm{~A}$, and those for SR-53 and SR-54 are $\mathrm{C}_{12} \mathrm{~A}_{7}$ and $\mathrm{C}_{2} \mathrm{AS}$. The dissolution behavior for the synthetic $\mathrm{C}_{11} \mathrm{~A}_{7} \cdot \mathrm{CaF}_{2}$ compound, which is represented by solid square is in agreement with that for the SR slags, as shown in Fig. 10. It can be expected from these results that $\mathrm{F}$ is incorporated into $\mathrm{C}-\mathrm{A}-\mathrm{H}$ compounds during the hydration of $\mathrm{CaO}-\mathrm{Al}_{2} \mathrm{O}_{3}$ mineral phases. Since the $\mathrm{Si}$ contents in all experiments are below $0.1 \mathrm{ppm}$, the hydration product of $\mathrm{C}-\mathrm{S}-\mathrm{H}$ gel is rapidly formed due to high hydration rate.

The relations between $\mathrm{F}$ and $\mathrm{Al}$, between $\mathrm{F}$ and $\mathrm{Ca}$ and between $\mathrm{Al}$ and $\mathrm{Ca}$ contents in aqueous solution are shown in Fig. 11 for the data of synthetic slags shown in Fig. 4 (molar ratio of $\mathrm{CaO} / \mathrm{Al}_{2} \mathrm{O}_{3}=3,5$ mass $\% \mathrm{~F}, 0-10$ mass $\%$ $\mathrm{SiO}_{2}$ ). A trend of the observed relations between $\mathrm{F}$ and $\mathrm{Al}$, $\mathrm{F}$ and $\mathrm{Ca}$ and $\mathrm{Al}$ and $\mathrm{Ca}$ contents is quite similar to that in Fig. 10; that is, the $\mathrm{Al}$ and $\mathrm{Ca}$ contents increase initially and then decrease along with the $\mathrm{F}$ content. The thick line in Fig. 11 indicates the corresponding results observed in Fig. 10. It can be seen that the final contents of $\mathrm{Ca}, \mathrm{Al}$ and $\mathrm{F}$ converge onto this line. This experimental finding indicates that the behavior of the formation of $\mathrm{C}-\mathrm{A}-\mathrm{H}-\mathrm{F}$ compounds
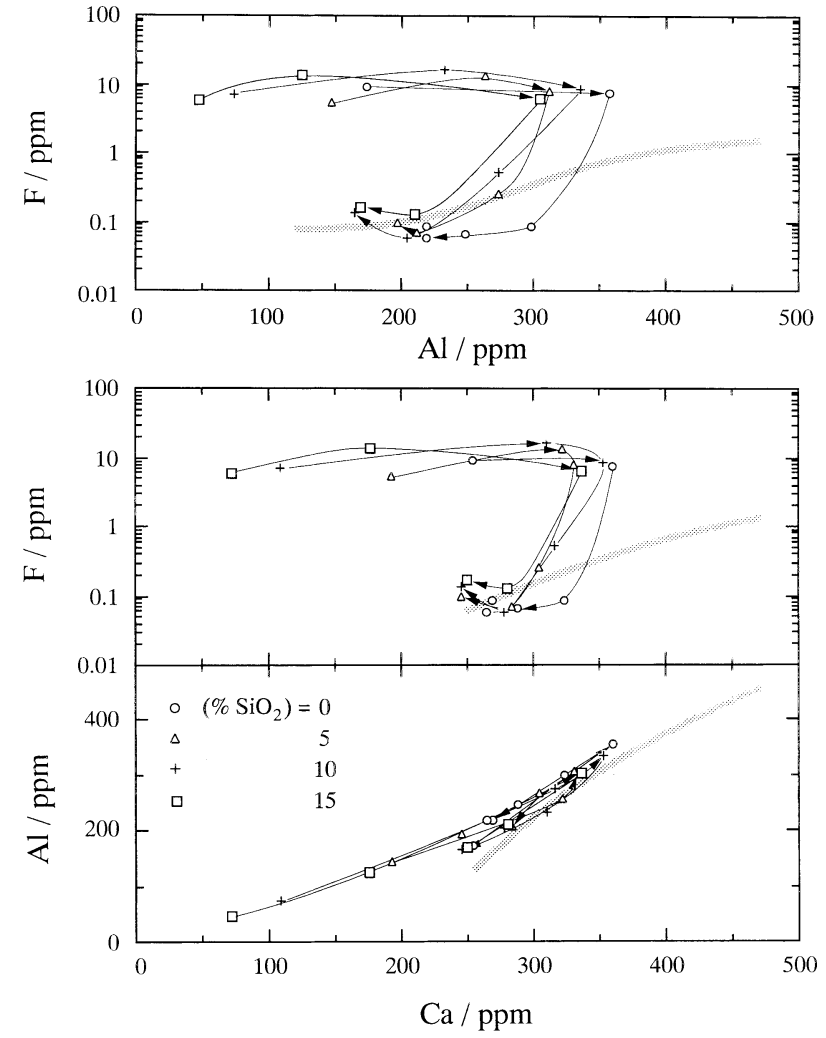

Fig. 11. Relations among solute contents in solution during dissolution of slowly cooled synthetic slags $\left(X_{\mathrm{CaO}} / X_{\mathrm{Al}_{2} \mathrm{O}_{3}}=3\right.$, $(\% \mathrm{~F})=5)$ : grain size $0.5-2 \mathrm{~mm}$.

during the hydration of synthetic slags is in agreement with that during the hydration of SR slags.

\subsubsection{Dissolution Mechanism of Fluorine}

The $\mathrm{F}$ contents in aqueous solution obtained after $6 \mathrm{~h}$ shaking for SR $(\leq 0.1 \mathrm{~mm})$ and synthetic $(0.5-2 \mathrm{~mm})$ slags are plotted against the $\mathrm{F}$ contents in slag in the upper diagram of Fig. 12 and are plotted against $(\% \mathrm{CaO}) /\left(\% \mathrm{SiO}_{2}\right)$ weight ratio in the lower diagram. It can be seen from the upper diagram that the $\mathrm{F}$ content in solution decreases with decreasing the F content in synthetic slags, although the data for the SR slags do not show this trend. From the results shown in the lower diagram, it is clear that the $\mathrm{F}$ content in solution decreases with an increase of the $(\% \mathrm{CaO}) /\left(\% \mathrm{SiO}_{2}\right)$ ratio. This finding can be interpreted in the following. Calcium, $\mathrm{Al}$ and $\mathrm{Si}$ also dissolve to aqueous solution during the shaking time, thus resulting in the precipitation of $\mathrm{C}-\mathrm{A}-\mathrm{H}$ hydration compound, $\mathrm{C}-\mathrm{S}-\mathrm{H}$ gel and $\mathrm{C}-\mathrm{A}-\mathrm{S}-\mathrm{H}$ gel, as given in Table 2 . It was experimentally confirmed that the amount of $\mathrm{C}-\mathrm{A}-\mathrm{H}$ hydration compound increases with increasing the $(\% \mathrm{CaO}) /\left(\% \mathrm{SiO}_{2}\right)$ ratio. As a result, the $\mathrm{F}$ content in solution decreases with an increase of the amount of this hydrate, because fluorine is incorporated into this compound and is stabilized. ${ }^{3)}$ On the other hand, the amount of $\mathrm{C}-\mathrm{S}-\mathrm{H}$ and $\mathrm{C}-\mathrm{A}-\mathrm{S}-\mathrm{H}$ gel increases with decreasing the $(\% \mathrm{CaO}) /\left(\% \mathrm{SiO}_{2}\right)$ ratio due to an increase of dissolved amount of $\mathrm{Si}$ from slag. However, the immobilization ability of $\mathrm{F}$ by these gels is much less than that by $\mathrm{C}-\mathrm{A}-\mathrm{H}$ hydration compound. ${ }^{6}$ ) This is the reason that the $\mathrm{F}$ content in solution increases, as shown in the lower diagram. For the immobilization of $F$ in SR slags the immobilization ability of hydration products is of great im- 

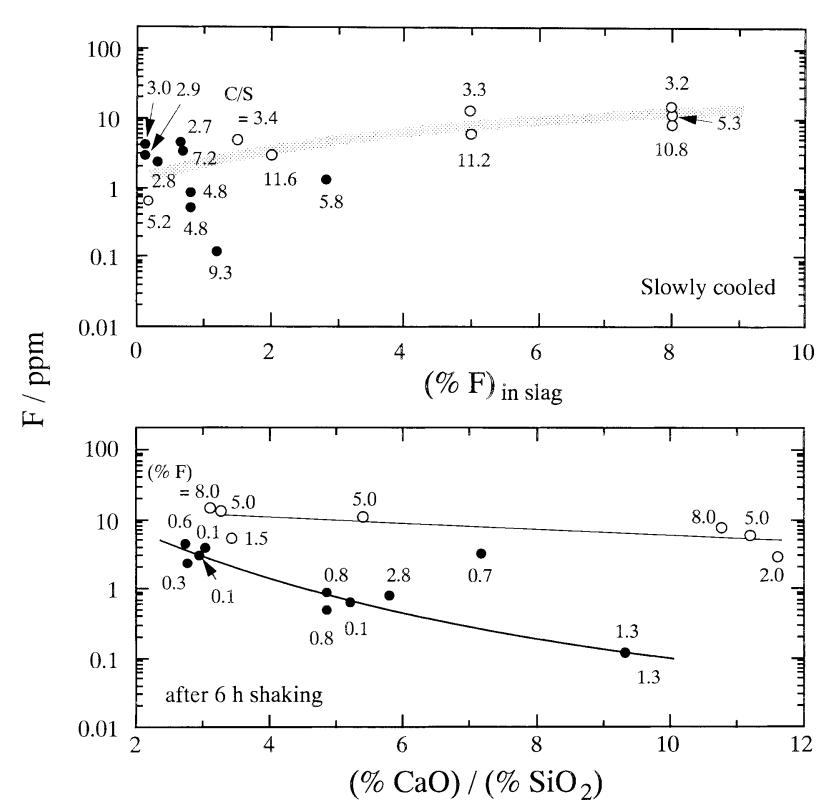

Fig. 12. Relation between fluorine content in solution and its content in slags (upper diagram) and between that and $\mathrm{CaO} / \mathrm{SiO}_{2}$ weight ratio (lower diagram): - SR slags $\left(X_{\mathrm{CaO}} / X_{\mathrm{Al} \mathrm{O}_{3}}=2.6-4.7\right.$, grain size $\left.\leq 0.1 \mathrm{~mm}\right), \bigcirc$ synthetic slags $\left(X_{\mathrm{CaO}^{2}} / X_{\mathrm{Al}_{2} \mathrm{O}_{3}}=3\right.$, grain size $\left.0.5-2 \mathrm{~mm}\right)$.

portance because not only the F dissolution occurs, but also the $\mathrm{F}$ incorporation by precipitation occurs simultaneously during the shaking test.

\subsection{Stabilization of Fluorine}

It was found that fluorine in the slags with low $\mathrm{SiO}_{2}$ and low T.Fe contents whose mineral phases are $\mathrm{C}_{3} \mathrm{~A}$ and $\mathrm{C}_{12} \mathrm{~A}_{7}$ is stabilized in the precipitation of $\mathrm{Ca}_{3} \mathrm{Al}_{2}(\mathrm{OH}, \mathrm{F})_{12}$ and $3 \mathrm{CaO} \cdot \mathrm{Al}_{2} \mathrm{O}_{3} \cdot \mathrm{Ca}(\mathrm{OH}, \mathrm{F})_{2} \cdot 18 \mathrm{H}_{2} \mathrm{O}$, as shown in Table 2 . Fluorine in the slags with high $\mathrm{SiO}_{2}$ and low T.Fe contents is immobilized mainly by $\mathrm{C}-\mathrm{S}-\mathrm{H}-\mathrm{F}$ gel, but the degree of $\mathrm{F}$ immobilization is not satisfactory. Therefore, the gypsum addition and hydrothermal treatment were made in order to stabilize $\mathrm{F}$ in the slags with high $\mathrm{SiO}_{2}$ and low T.Fe contents.

\subsubsection{Gypsum Addition}

Gypsum was added to the solution containing the SR slags with high $\mathrm{SiO}_{2}$ and low T.Fe contents (SR-D) or with low $\mathrm{SiO}_{2}$ and low T.Fe contents (SR-52) at the ratio of slag/gypsum $=1 / 4$ in weight. The results for these slags are shown in Figs. 13 and 14, respectively. It can be seen from the results shown in Fig. 13 that the addition of gypsum to the slags with high $\mathrm{SiO}_{2}$ and low T.Fe contents is very effective to the $\mathrm{F}$ immobilization by the formation of $\mathrm{C}-\mathrm{S}-$ $\mathrm{H}-\mathrm{SO}_{4}-\mathrm{F}$ gel and other hydration products given in Table 2 . These hydration products were identified by XRD and EPMA-WDX for the filtered residue after the shaking test. However, the addition of gypsum to the solution containing the SR slag with low $\mathrm{SiO}_{2}$ and low T.Fe contents whose major mineral phases are $\mathrm{C}_{3} \mathrm{~A}$ and $\mathrm{C}_{12} \mathrm{~A}_{7}$, has an adverse effect on $\mathrm{F}$ immobilization, as shown in Fig. 14. This is due to the fact that $\mathrm{SO}_{4}^{2-}$ ion in solution reacts with $\mathrm{C}_{3} \mathrm{~A}$ and $\mathrm{C}_{12} \mathrm{~A}_{7}$ phases on the particle surface, leading to the formation of ettringite $\left(3 \mathrm{CaO} \cdot \mathrm{Al}_{2} \mathrm{O}_{3} \cdot 3 \mathrm{Ca}\left(\mathrm{SO}_{4}, \mathrm{~F}_{2}\right) \cdot 32 \mathrm{H}_{2} \mathrm{O}\right)$ and monosulfates $\left(3 \mathrm{CaO} \cdot \mathrm{Al}_{2} \mathrm{O}_{3} \cdot \mathrm{Ca}\left(\mathrm{SO}_{4}, \mathrm{~F}_{2}\right) \cdot 12 \mathrm{H}_{2} \mathrm{O}\right.$ and

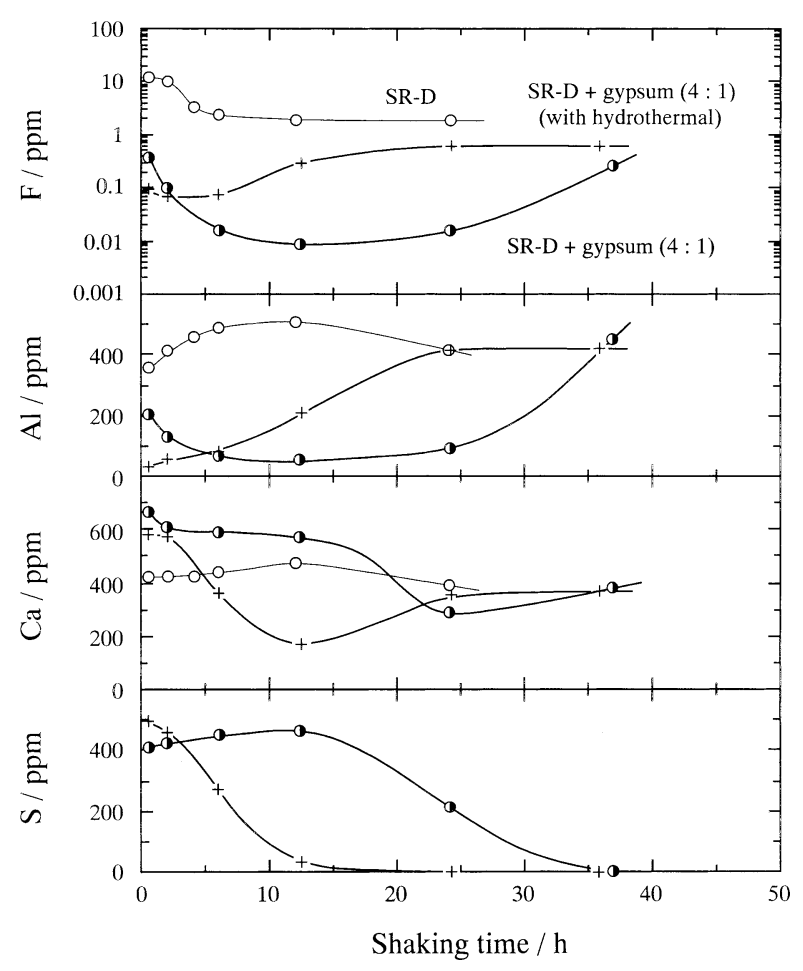

Fig. 13. Variation with shaking time of F content in solution dissolved from the mixture of secondary refining slag with high $\mathrm{SiO}_{2}$ and low T.Fe contents (grain size $\leq 0.1 \mathrm{~mm}$ ) and gypsum, and that after hydrothermal treatment.

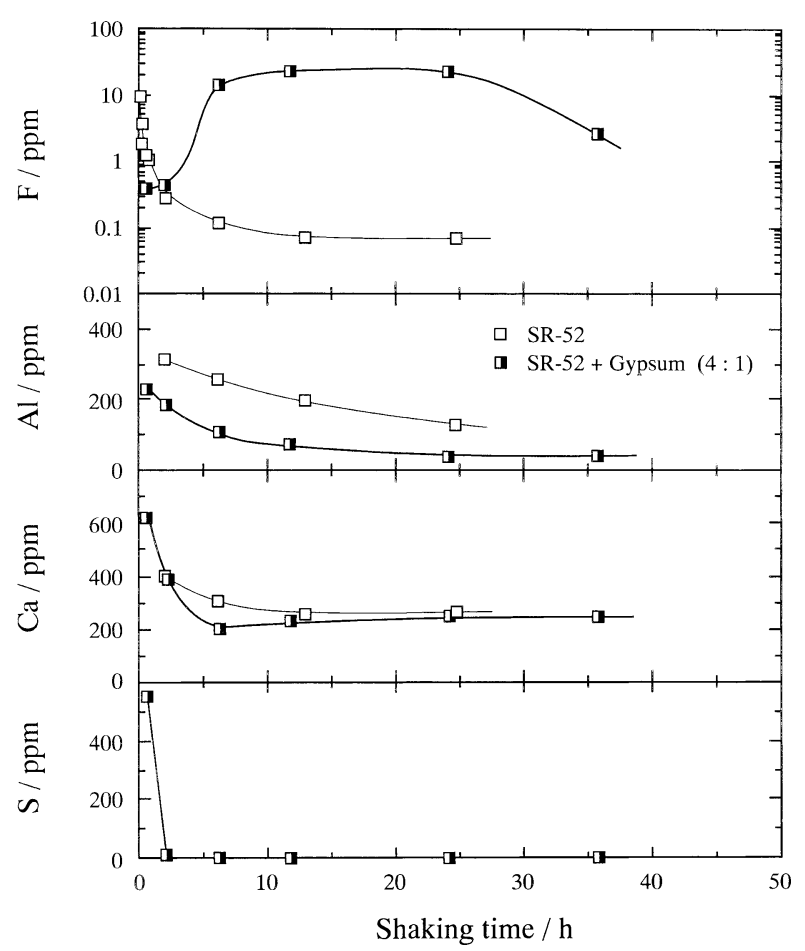

Fig. 14. Variation with shaking time of $\mathrm{F}$ content in solution dissolved from the mixture of secondary refining slag with low $\mathrm{SiO}_{2}$ and low T.Fe contents (grain size $\leq 0.1 \mathrm{~mm}$ ) and gypsum.

$\left.3 \mathrm{CaO} \cdot \mathrm{Al}_{2} \mathrm{O}_{3} \cdot \mathrm{Ca}\left(\mathrm{SO}_{4}, \mathrm{~F}_{2}\right) \cdot 14 \mathrm{H}_{2} \mathrm{O}\right)$. This protective reaction layer prevents the continuous dissolution of $\mathrm{Al}$ and $\mathrm{Ca}$ from SR slag surface, which contributes to the $\mathrm{F}$ immobilization by precipitation of $\mathrm{C}-\mathrm{A}-\mathrm{H}$ hydrate. The behavior that low content of $\mathrm{F}$ at initial period, followed by an increase of $\mathrm{F}$ 


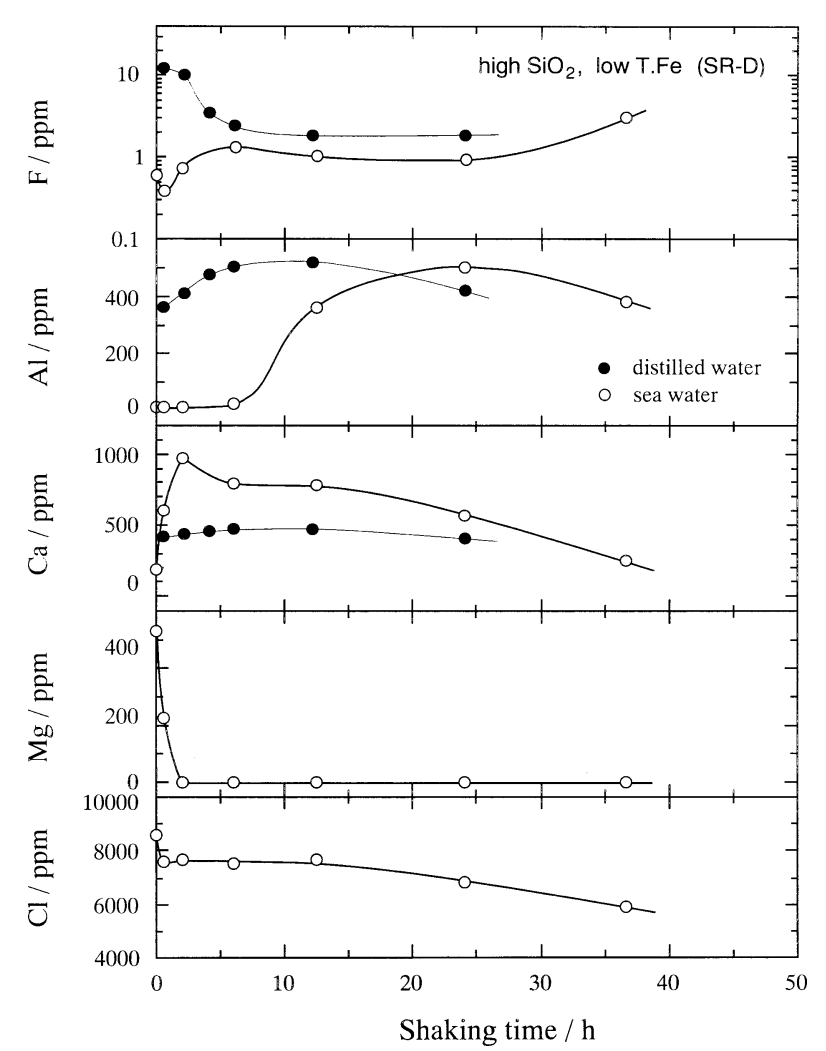

Fig. 15. Variation with shaking time of solute contents in seawater dissolved from conventionally cooled secondary refining slag with high $\mathrm{SiO}_{2}$ and low T.Fe contents: grain size $\leq 0.1 \mathrm{~mm}$.

content, as shown in the upper diagram of Fig. 14, can be explained by the behavior of sulfur content in solution. The decrease of $\mathrm{F}$ content after $24 \mathrm{~h}$ is explained by peeling-off of the ettringite layer on particles, which prevents the F immobilization.

\subsubsection{Hydrothermal Treatment}

The mixture of slag containing high $\mathrm{SiO}_{2}$ and low T.Fe slag with gypsum (4:1 in weight) was pressed (200 $\mathrm{kg} / \mathrm{mm}^{2}$ ) and treated hydrothermally at $80^{\circ} \mathrm{C}$ for $3 \mathrm{~h}$, followed by crushing under $0.1 \mathrm{~mm}$. The results for the shaking test are shown by plus marks in Fig. 13. It can be seen that the F content is extremely low at initial time, but starts to gradually increase after $6 \mathrm{~h}$. The XRD and EPMA-WDX analysis for the filtered residue after the hydrothermal treatment reveals that major hydration products are $\mathrm{C}-\mathrm{S}-$ $\mathrm{H}-\mathrm{SO}_{4}-\mathrm{F}$ gel and $\mathrm{C}-\mathrm{S}-\mathrm{A}-\mathrm{H}-\mathrm{SO}_{4}-\mathrm{F}$ gel, and minor ones are $\mathrm{Ca}_{10}\left(\mathrm{SiO}_{4}\right)_{3}\left(\mathrm{SO}_{4}\right)_{3}(\mathrm{OH}, \mathrm{F})_{2}, \mathrm{Ca}_{5}\left(\mathrm{SiO}_{4}, \mathrm{SO}_{4}\right)_{3}(\mathrm{OH}, \mathrm{F})$ and $\mathrm{Ca}_{2} \mathrm{Al}_{2} \mathrm{SiO}_{6}(\mathrm{OH}, \mathrm{F})_{2}$, as listed in Table 2. These hydration products except for $\mathrm{Ca}_{2} \mathrm{Al}_{2} \mathrm{SiO}_{6}(\mathrm{OH}, \mathrm{F})_{2}$ are also identified for the filtered residue obtained after the shaking test in the mixture of SR slag and gypsum without hydrothermal treatment. It is clear from these results that $\mathrm{C}_{2} \mathrm{AS}$ is easily hydrated under the hydrothermal condition.

\subsection{Dissolution Behavior in Seawater}

Dissolution behavior in seawater has been studied by using the SR slag (SR-D, $\leq 0.1 \mathrm{~mm}$ ) with high $\mathrm{SiO}_{2}$ and low T.Fe contents. The solute contents are plotted against shaking time in Fig. 15 together with those obtained in distilled water in shaking test. The Si content was found to be below the analytical limit. The hydration products, which were identified by XRD, EPMA-EDX and EPMA-WDX for the filtered residue after the shaking test, are $\mathrm{Mg}(\mathrm{OH}$, F) ${ }_{3} \mathrm{Cl}_{3} \cdot 2 \mathrm{H}_{2} \mathrm{O}, \mathrm{C}_{3} \mathrm{~A} \cdot \mathrm{Ca}\left(\mathrm{Cl}_{1-x} \mathrm{~F}_{x}\right)_{2} \cdot 10 \mathrm{H}_{2} \mathrm{O}(x=0-0.4), \mathrm{C}-\mathrm{S}-$ $\mathrm{H}-\mathrm{Cl}-\mathrm{F}$ gel $(\mathrm{Cl}=0-3 \%, \mathrm{~F}=0-0.4 \%)$ and hydration products without containing $\mathrm{F}$ such as $\mathrm{Mg}_{5} \mathrm{Al}(\mathrm{Si}, \mathrm{Al})_{4} \mathrm{O}_{10}(\mathrm{OH})_{m}$ $(m=1,8)$ and $\mathrm{Ca}_{2} \mathrm{Al}(\mathrm{OH})_{7} \cdot 3 \mathrm{H}_{2} \mathrm{O}$.

On the basis of these hydration products and the solute behavior shown in Fig. 15, the fluorine dissolution mechanism from SR slag in seawater can be explained as follows: Rapid decrease of $\mathrm{F}, \mathrm{Mg}$ and $\mathrm{Cl}$ contents at initial time suggests that $\mathrm{F}$ is immobilized in the form of $\mathrm{Mg}(\mathrm{OH}$, F) ${ }_{3} \mathrm{Cl}_{3} \cdot 2 \mathrm{H}_{2} \mathrm{O}$. Furthermore in this period the $\mathrm{Ca}$ content increases and the $\mathrm{Al}$ content remains almost zero, suggesting the precipitation of $\mathrm{Mg}_{5} \mathrm{Al}(\mathrm{Si}, \mathrm{Al})_{4} \mathrm{O}_{10}(\mathrm{OH})_{m}$. From the results that the $\mathrm{Ca}$ content starts to decrease after the $\mathrm{Mg}$ content becomes almost zero at $2 \mathrm{~h}$ shaking time, it is considered that the precipitation of $\mathrm{C}_{3} \mathrm{~A} \cdot \mathrm{Ca}\left(\mathrm{Cl}_{1-x} \mathrm{~F}_{x}\right)_{2} \cdot 10 \mathrm{H}_{2} \mathrm{O}$ and $\mathrm{Ca}_{2} \mathrm{Al}(\mathrm{OH})_{7} \cdot 3 \mathrm{H}_{2} \mathrm{O}$ occurs. However, due to low degree of $\mathrm{F}$ stabilization by these hydrates the $\mathrm{F}$ content starts to increase. The Al content increases and the $\mathrm{Ca}$ content decreases with increasing shaking time in the range above $6 \mathrm{~h}$. This finding reveals that $\mathrm{F}$ cannot be stabilized because main precipitate is $\mathrm{Ca}_{2} \mathrm{Al}(\mathrm{OH})_{7} \cdot 3 \mathrm{H}_{2} \mathrm{O}$ which does not incorporate $\mathrm{F}$. Although $\mathrm{C}-\mathrm{S}-\mathrm{H}-\mathrm{Cl}-\mathrm{F}$ gel is formed as a result of Si dissolution from SR slag, the stabilization ability of this gel is lower than that of $\mathrm{C}-\mathrm{S}-\mathrm{H}-\mathrm{SO}_{4}-\mathrm{F}$ gel. $\left.{ }^{7}\right)$ Therefore, the $\mathrm{F}$ stabilization by this gel is considered to be small.

\section{Conclusions}

The dissolution behavior of fluorine in secondary refining and synthetic $\mathrm{CaO}-\mathrm{Al}_{2} \mathrm{O}_{3}-\mathrm{SiO}_{2}\left(-\mathrm{P}_{2} \mathrm{O}_{5}\right)$ slags has been studied and the immobilization of $\mathrm{F}$ through the formation of $\mathrm{CaO}-\mathrm{SiO}_{2}-\mathrm{H}_{2} \mathrm{O}-\mathrm{SO}_{4}-\mathrm{F}$ gel has been proposed by the addition of gypsum. The main results obtained are summarized in the following.

(1) The F content dissolved from secondary refining slags decreases with decreasing the contents of $\mathrm{SiO}_{2}$ and $\mathrm{F}$ in slag due to the incorporation of $\mathrm{F}$ into $\mathrm{CaO}-\mathrm{Al}_{2} \mathrm{O}_{3}-\mathrm{H}_{2} \mathrm{O}$ compounds precipitated in aqueous solution.

(2) For the slags containing low $\mathrm{SiO}_{2}$ and high total $\mathrm{Fe}$ content where the amount of $12 \mathrm{CaO} \cdot(7-x) \mathrm{Al}_{2} \mathrm{O}_{3} \cdot x \mathrm{Fe}_{2} \mathrm{O}_{3}$ phase is large, the $\mathrm{F}$ content in solution decreases with shaking time after reaching the maximum due to slow precipitation process of $\mathrm{CaO}-\mathrm{Al}_{2} \mathrm{O}_{3}-\mathrm{Fe}_{2} \mathrm{O}_{3}-\mathrm{H}_{2} \mathrm{O}$ compound containing $\mathrm{F}$.

(3) For the slags containing high $\mathrm{SiO}_{2}$ and low total $\mathrm{Fe}$ contents the $\mathrm{F}$ content in solution decreases slowly with shaking time through the incorporation of $\mathrm{F}$ into $\mathrm{CaO}-$ $\mathrm{SiO}_{2}-\mathrm{Al}_{2} \mathrm{O}_{3}-\mathrm{H}_{2} \mathrm{O}$ gel.

(4) When gypsum is added to the solution containing the slags with high $\mathrm{SiO}_{2}$ and low total Fe contents, the $\mathrm{F}$ content in solution decreases considerably with shaking time due to the formation of $\mathrm{CaO}-\mathrm{SiO}_{2}-\mathrm{SO}_{4}-\mathrm{H}_{2} \mathrm{O}-\mathrm{F}$ gel.

(5) When gypsum is added to the solution containing the slags with low $\mathrm{SiO}_{2}$ and low total Fe contents, ettringite and monosulfate are formed on slag particle surface which retards the precipitation of F-containing compounds in solution.

(6) Fluorine dissolved from SR slag to seawater is sta- 
ISIJ International, Vol. 42 (2002), No. 8

bilized through the precipitation of $\mathrm{Mg}(\mathrm{OH}, \mathrm{F})_{3} \mathrm{Cl}_{3} \cdot 2 \mathrm{H}_{2} \mathrm{O}$.

\section{REFERENCES}

1) R. Inoue and H. Suito: ISIJ Int., 42 (2002), 785.

2) H. Suito and R. Inoue: Tetsu-to-Hagané, 88 (2002), 347.
3) H. He and H. Suito: ISIJ Int., 41 (2001), 506.

4) H. He and H. Suito: ISIJ Int., 42 (2002), 132.

5) H. He and H. Suito: ISIJ Int., 42 (2002), 794.

6) H. He and H. Suito: ISIJ Int., 41 (2001), 513.

7) R. Inoue and H. Suito: ISIJ Int., 42 (2002), 930. 